\title{
CORRELATION BETWEEN VITAMIN D LEVEL AND BONE MINERAL DENSITY IN EGYPTIAN PATIENTS WITH SECONDARY HYPERPARATHYROIDISM
}

\author{
By \\ Mohamed Kamal Gomaa ${ }^{1}$, Abdulmaguid Abdulaty Elashmawy ${ }^{2}$, Abd El- \\ Shafi Ahmed Hasseb ${ }^{3}$, and Ahmed Mohamed Tahoun ${ }^{4}$ \\ ${ }^{1,2,3}$ Department of Rheumatology and Rehabilitation, Faculty of Medicine, Al-Azhar \\ University, Cairo, Egypt \\ ${ }^{4}$ Department of Clinical Pathology, Faculty of medicine, Al-Azhar University, Cairo, \\ Egypt
}

Corresponding author: Mohamed Kamal Gomaa,

Mobile: 01121262773, E-mail: drmahamadkamal@gmail.com

\begin{abstract}
Background: There is still limited data on the association between 25-hydroxyvitamin D, parathyroid hormone (PTH) and bone mineral density (BMD) in Egypt.

Objective: To correlate between vitamin D level and bone mineral density in Egyptian patients with secondary hyperparathyroidism.

Patients and Methods: Fifty female patients with secondary hyperparathyroidism recruited for the study from Rheumatology and Rehabilitation Outpatient Clinic of Al-Azhar University Hospitals, in addition to another fifty age matched control group healthy individuals after an informed consent from all subjects starting from November 2019 till may 2020. In this study, we measure parathormone hormone level, 25Hydroxyvitamin D, serum calcium (total and ionized). Assessment of bone mineral density measured by dual-energy x-ray absorptiometry at lumbar spine, left proximal femur, and left distal forearm.
\end{abstract}

Results: Lt Forearm BMD was significantly lower in the 50 women with secondary hyperparathyroidism than in the 50 with normal PTH levels. The mean t-score \pm SD was $-1.2 \pm 0.93$, and $0.5 \pm 1.37$ respectively. Thirty five $(70 \%)$ was vit D deficient with mean t-score of the Lt Forearm $-1.6 \pm 1.48$ (osteopenia), and fifteen $(30 \%)$ was vit D insufficient with normal t-score of all bone parameters in this group.

Conclusion: Our study revealed that positive correlation and significance between Vit D with serum calcium (total and ionized), BMD and t score (AP spine, Lt Femur, and Lt forearm), while negative correlation and significance between BMD (AP spine, Lt femur, and Lt forearm) with PTH, and negative correlation and significance between vit D with PTH.

Keywords: Secondary hyperparathyroidism, parathyroid hormone, vitamin D, bone mineral density.

\section{INTRODUCTION}

Vitamin $\mathrm{D}$ is a steroid hormone responsible for maintaining calcium and phosphate homeostasis. Humans endogenously synthesize vitamin $\mathrm{D}$ in the skin upon exposure to ultraviolet B radiation and exogenously derive vitamin D from dietary sources and supplements. Once entering the circulation, vita-min D undergoes liver hydroxylation by 25 - 
hydroxylase enzyme and turns into 25hydroxyvitamin D $(25(\mathrm{OH}) \mathrm{D})$, which is generally measured for assessment of vitamin D status.25(OH)D is then converted by $1 \alpha$-hydroxylase enzyme in the kidney into the active from of 1,25dihydroxyvitamin $\mathrm{D}(1,25(\mathrm{OH}) 2 \mathrm{D})$ that exerts physiological functions by promoting intestinal calcium and phosphate absorption, renal tubular reabsorption of calcium, and bone resorption and formation (Charoenngam et al., 2019).

Deficiency of vitamin D was linked to secondary hyperparathyroidism and bone loss, with decreased BMD and increased risk of osteoporosis (Ebeling, 2014).

The general consensus on vitamin D deficiency suggests that deficiency exists when serum 25-hydroxyvitamin D levels are less than $50 \mathrm{nmol} / \mathrm{L}(20 \mathrm{ng} / \mathrm{mL})$, with insufficiency in the range from $50 \mathrm{nmol} / \mathrm{L}$ to $75 \mathrm{nmol} / \mathrm{L}$, and sufficiency above $75 \mathrm{nmol} / \mathrm{L}(30 \mathrm{ng} / \mathrm{mL})$.Vitamin D status is measured in the blood using 25Hydroxyvitamin D measurements. Keeping recommended vitamin D levels is essential for bone health. Sources of vitamin $\mathrm{D}$ include adequate sunlight exposure, and adequate dietary intake of vitamin D. Supplements should be used where there is inadequate amount of vitamin D (Holick et al., 2011).

The present work aimed to correlate between vitamin $\mathrm{D}$ level and bone mineral density in Egyptian patients with secondary hyperparathyroidism, and to determine in the Egyptian population link between the vitamin $\mathrm{D}$ deficiency and osteoporosis.

\section{PATIENTS AND METHODS}

The ethical approval was obtained from the hospital ethical research committee. Fifty female patients with secondary hyperparathyroidism recruited for the study from Rheumatology and Rehabilitation Outpatient Clinic of AlAzhar University Hospitals, in addition to another fifty age matched control group, after obtaining informed consents from all subjects. This work started from November 2019 till May 2020. We measured parathormone hormone level, 25-Hydroxyvitamin D, serum calcium (total and ionized). Assessment of bone mineral density measured by dual-energy $\mathrm{x}$-ray absorptiometry at lumbar spine, left proximal femur and left distal forearm. Densitometer was calibrated daily, and quality assurance was performed monthly.

\section{Inclusion criteria:}

This included an existing diagnosis of elevated parathormone hormone for secondary hyperparathyroidism.

\section{Exclusion criteria:}

Primary hyperparathyroidism diagnosis with elevated serum calcium and unrestrained levels with PTH.

- Patients with conditions associated with malabsorption of vitamin D.

- Patients taking any medication(s) that can adversely affect bone metabolism and thus lead to decreased BMD by causing deficiency of vitamin D.

- Patients with a $50 \mathrm{ml} / \mathrm{min}$ creatinine clearance. Below this stage, $25(\mathrm{OH}) \mathrm{D}$ to 1,25 -hydroxyvitamin $\mathrm{D}$ has impaired hydroxylation. 
- Patients who received vitamin D supplements, and mothers who were pregnant or lactating.

All patients were subjected to the following:

1. Careful history taking.

2. Musculoskeletal examination.

3. The following laboratory investigations were done for all cases:

a. Parathormone hormone level by chemoillumicience technique and serum calcium (total and ionized).

b. 25-Hydroxyvitamin D Level of serum 25-Hydroxycholecalciferol [25- $(\mathrm{OH}) \mathrm{D}]$ by Chemoillumicience technique.

4. Bone Quantity Assessment was measured by dual-energy X-ray absorptiometry at lumbar spine, left proximal femur and left distal forearm. Densitometer was calibrated daily, and quality assurance was performed monthly.

Type of apparatus: GE Medical System (GE-Lunar Prodigy Primo) Madison, WI, USA Brand: GE-Lunar Model: Prodigy.
Bone mineral density (BMD) or bone mass is one of the predictors of fracture. With the availability of high precision bone densitometers, the World Health Organization has established criteria for diagnosing osteoporosis.

The diagnostic score ( $\mathrm{t}$-score) is related to bone mass in young healthy women. Bone mineral density (BMD) above -1 SD (standard deviation) is normal, BMD between -1 and $-2.5 \mathrm{SD}$ is assigned to osteopenia, while below $-2.5 \mathrm{SD}$ is the diagnostic criterion for osteoporosis ( $\mathrm{T}$ score) BMD is preferably measured by dual energy X-ray absorptiometry (DXA).

\section{Statistical analysis:}

Data were analyzed using Statistical program for Social Science (SPSS) version 26.0. Quantitative data were expressed as mean \pm standard deviation (SD). Qualitative data were expressed as frequency and percentage.

\section{RESULTS}

Regarding patients' characteristics, there were statistically significant differences between groups according to
Age, PTH, S.Ca T, Vit D, BMD and T score (AP spine, Lt femur, Lt forearm) (Table 1). 
Table (1): Comparison between cases and controls regarding patients' characteristics

\begin{tabular}{|c|c|c|c|}
\hline \begin{tabular}{|ll} 
Variables & Groups \\
\end{tabular} & $\begin{array}{c}\text { Cases } \\
(n=50)\end{array}$ & $\begin{array}{c}\text { Controls } \\
(\mathbf{n}=50)\end{array}$ & $\begin{array}{c}\text { P- } \\
\text { value }\end{array}$ \\
\hline \multirow{2}{*}{$\begin{array}{lr}\bullet & \text { Age } \\
\text { Mean } \pm \text { SD. } \\
\bullet \quad \text { PTH } \\
\text { Mean } \pm \text { SD. }\end{array}$} & $33.6 \pm 10.12$ & $39.7 \pm 7.45$ & 0.002 \\
\hline & 12 & 53 & $<0.001$ \\
\hline \multirow{2}{*}{$\begin{array}{l}\text { - S.Ca T } \\
\text { Mean } \pm \text { SD. }\end{array}$} & & & \multirow{2}{*}{$<0.001$} \\
\hline & $8.4 \pm 0.84$ & $9.2 \pm 0.66$ & \\
\hline $\begin{array}{l}\bullet \quad \text { S.Ca I } \\
\text { Mean } \pm \text { SD. }\end{array}$ & $1.5 \pm 0.74$ & $1.4 \pm 0.41$ & 0.225 \\
\hline \multirow{2}{*}{ - Vit D } & & & \multirow{2}{*}{$<0.001$} \\
\hline & $13.2 \pm 8.14$ & $42.3 \pm 11.25$ & \\
\hline \multirow{5}{*}{$\begin{array}{l}\bullet \quad \text { AP spine } \\
\text { BMD Mean } \pm \text { SD. } \\
\text { T score Mean } \pm \text { SD. } \\
\text { - } \quad \text { Lt femur } \\
\text { BMD Mean } \pm \text { SD. } \\
\text { T score Mean } \pm \text { SD. } \\
\text { - Lt Forearm }\end{array}$} & $1.1 \pm$ & 15 & \multirow{2}{*}{$\begin{array}{l}<0.001 \\
<0.001\end{array}$} \\
\hline & $-0.8 \pm 1.33$ & $0.3 \pm 1.07$ & \\
\hline & $0.9 \pm 0$ & $1.1 \pm 0.10$ & \multirow{2}{*}{$\begin{array}{l}<0.001 \\
<0.001\end{array}$} \\
\hline & $-0.5 \pm 1.45$ & $0.6 \pm 0.73$ & \\
\hline & & & \multirow[b]{2}{*}{$\begin{array}{l}<0.001 \\
<0.001\end{array}$} \\
\hline $\begin{array}{l}\text { BMD Mean } \pm \text { SD. } \\
\text { T score Mean } \pm \text { SD. }\end{array}$ & $\begin{array}{r}0.6 \pm 0.10 \\
-1.2 \pm 1.57\end{array}$ & $\frac{0.7 \pm 0.11}{0.5 \pm 1.37}$ & \\
\hline
\end{tabular}

Regarding to relation between age, laboratory, bone parameters and Vit D groups in cases, there were statistically significant differences between age,

Table (2): Relation between age, laboratory, bone parameters and Vit D groups in Cases

\begin{tabular}{|c|c|c|c|}
\hline $\begin{array}{ll}\text { Variables } & \text { Vit D groups } \\
\end{array}$ & $\begin{array}{c}\text { Deficiency } \\
(<20)(n=35)\end{array}$ & $\begin{array}{c}\text { Insufficiency } \\
(20-30)(n=15)\end{array}$ & P-value \\
\hline \multirow{2}{*}{$\begin{array}{l}-\quad \text { Age } \\
\text { Mean } \pm \text { SD. }\end{array}$} & & & \multirow{2}{*}{0.022} \\
\hline & $35.8 \pm 9.22$ & $28.4 \pm 10.58$ & \\
\hline \multirow{2}{*}{$\begin{array}{l}\bullet \quad \text { PTH } \\
\text { Mean } \pm \text { SD. }\end{array}$} & & & \multirow{2}{*}{0.007} \\
\hline & $174.1 \pm 121.27$ & $85.7 \pm 16.10$ & \\
\hline \multirow{2}{*}{$\begin{array}{l}\text { S.Ca T } \\
\text { Mean } \pm \text { SD. }\end{array}$} & & & \multirow{2}{*}{0.004} \\
\hline & $8.2 \pm 0.81$ & $8.9 \pm 0.66$ & \\
\hline \multirow{2}{*}{$\begin{array}{l}\text { S.Ca I } \\
\text { Mean } \pm \text { SD. }\end{array}$} & & & \multirow{2}{*}{0.181} \\
\hline & $1.5 \pm 0.76$ & $1.5 \pm 0.72$ & \\
\hline \multirow{3}{*}{$\begin{array}{l}-\quad \text { AP spine } \\
\text { BMD Mean } \pm \text { SD. } \\
\text { T score Mean } \pm \text { SD. } \\
\text { - } \quad \text { Lt femur }\end{array}$} & & & \multirow{2}{*}{$\begin{array}{l}\text { 0.047 } \\
\text { 0.021 }\end{array}$} \\
\hline & $\begin{array}{c}1.1 \pm 0.17 \\
-1.1 \pm 1.40\end{array}$ & $\begin{array}{c}1.2 \pm 0.13 \\
-0.1 \pm 0.87\end{array}$ & \\
\hline & & & \multirow{3}{*}{$\begin{array}{l}0.032 \\
0.038\end{array}$} \\
\hline \multirow{5}{*}{$\begin{array}{l}\text { BMD Mean } \pm \text { SD. } \\
\text { T score Mean } \pm \text { SD. } \\
\text { - Lt Forearm } \\
\text { BMD Mean } \pm \text { SD. } \\
\text { T score Mean } \pm \text { SD. }\end{array}$} & $0.9 \pm 0.14$ & $1.0 \pm 0.20$ & \\
\hline & $-0.8 \pm 1.23$ & $0.2 \pm 1.69$ & \\
\hline & & & \multirow{3}{*}{$\begin{array}{l}0.044 \\
0.015\end{array}$} \\
\hline & $0.6 \pm 0.10$ & $0.6 \pm 0.09$ & \\
\hline & $-1.6 \pm 1.48$ & $-0.4 \pm 1.54$ & \\
\hline
\end{tabular}


Regarding to relation between age, laboratory parameters and AP spine $\mathrm{t}$ score in cases, there were statistically significant differences between age, laboratory parameters and AP spine $t$ score in Cases according to PTH, S.Ca T and Vit D and no statistically significant difference between age, laboratory parameters and AP spine t score in cases according to age and s.Ca I (Table 3).

Table (3): Relation between age, laboratory parameters and AP spine $t$ score in Cases

\begin{tabular}{|c|c|c|c|c|}
\hline Variables & $\begin{array}{c}\text { Normal } \\
(n=30)\end{array}$ & $\begin{array}{c}\text { Osteopenia } \\
(\mathbf{n}=15)\end{array}$ & $\begin{array}{c}\text { Osteoporosis } \\
(\mathbf{n = 5})\end{array}$ & $\begin{array}{c}P \text { - } \\
\text { value }\end{array}$ \\
\hline \multirow{3}{*}{$\begin{array}{lr} & \text { Age } \\
\text { Mean } & \pm \text { SD. } \\
& \text { PTH }\end{array}$} & & & & \multirow[t]{2}{*}{0.392} \\
\hline & $32.3 \pm 10.13$ & $35.7 \pm 10.71$ & $36.0 \pm 8.51$ & \\
\hline & $120.9 \pm 93.89$ & $145.8 \pm 85.72$ & $323.0 \pm 120.36$ & 0.002 \\
\hline $\begin{array}{l}\text { Mean } \pm \text { SD. } \\
\text { S.Ca T }\end{array}$ & $8.6 \pm 0.84$ & $8.3 \pm 0.79$ & $7.6 \pm 0.33$ & $\mathbf{0 . 0 3 3}$ \\
\hline \multirow{4}{*}{$\begin{array}{l}\text { Mean } \pm \text { SD. } \\
\bullet \quad \text { S.Ca I } \\
\text { Mean } \pm \text { SD. } \\
\bullet \quad \text { Vit D } \\
\text { Mean } \pm \text { SD. }\end{array}$} & & & & \multirow{2}{*}{0.157} \\
\hline & $1.6 \pm 0.84$ & $1.3 \pm 0.42$ & $1.3 \pm 0.81$ & \\
\hline & & & & \multirow[t]{2}{*}{0.005} \\
\hline & $15.4 \pm 8.59$ & $11.5 \pm 6.13$ & $4.9 \pm 2.76$ & \\
\hline
\end{tabular}

Regarding to relation between age, laboratory parameters and Lt femur t score in cases, there were statistically significant differences between age, laboratory parameters and $\mathrm{Lt}$ femur $\mathrm{t}$ score in cases according to age , PTH , s.Ca I and shows no statistically significant difference between age, laboratory parameters and $\mathrm{Lt}$ Femur $\mathrm{t}$ score in Cases according to S.Ca T, Vit D (Table 4).

Table (4): Relation between age, laboratory parameters and Lt Femur $t$ score in Cases

\begin{tabular}{|c|c|c|c|c|}
\hline \begin{tabular}{|l} 
Lt Femur t \\
Score
\end{tabular} & $\begin{array}{c}\text { Normal } \\
(n=28)\end{array}$ & $\begin{array}{c}\text { Osteopenia } \\
(\mathbf{n}=19)\end{array}$ & $\begin{array}{l}\text { Osteoporosis } \\
\quad(\mathbf{n}=\mathbf{3})\end{array}$ & $\begin{array}{c}P \text { - } \\
\text { value }\end{array}$ \\
\hline \multirow{2}{*}{$\begin{array}{lr}\bullet & \text { Age } \\
\text { Mean } \pm \text { SD. }\end{array}$} & & & & \multirow{2}{*}{$<0.001$} \\
\hline & $37.2 \pm 8.58$ & $26.5 \pm 2.02$ & $44.0 \pm 1.73$ & \\
\hline \multirow{2}{*}{$\begin{array}{l}-\quad \text { PTH } \\
\text { Mean } \pm \text { SD. }\end{array}$} & & & & \multirow[t]{2}{*}{0.003} \\
\hline & $104.9 \pm 61.44$ & $190.0 \pm 126.19$ & $300.0 \pm 161.00$ & \\
\hline - $\quad$ S.Ca T & & & & \multirow{2}{*}{0.072} \\
\hline \multirow{2}{*}{$\begin{array}{l}\text { Mean } \pm \text { SD. } \\
\text { S.Ca I }\end{array}$} & $8.6 \pm 0.86$ & $8.1 \pm 7.4$ & $7.8 \pm 0.54$ & \\
\hline & & & & \multirow{2}{*}{$\mathbf{0 . 0 3 3}$} \\
\hline \multirow{3}{*}{$\begin{array}{l}\text { Mean } \pm \text { SD. } \\
\qquad \quad \text { Vit D } \\
\text { Mean } \pm \text { SD. }\end{array}$} & $1.6 \pm 0.75$ & $1.4 \pm 0.74$ & $0.9 \pm 0.19$ & \\
\hline & & & & \multirow{2}{*}{0.112} \\
\hline & $14.6 \pm 8.14$ & $12.3 \pm 8.18$ & $5.8 \pm 3.32$ & \\
\hline
\end{tabular}

Regarding to relation between age, laboratory parameters and Lt Forearm t score in Cases, there was statistically significant difference between age, laboratory parameters and Lt Forearm $\mathrm{t}$ score in Cases according to Age, PTH, S.Ca T\&I ,Vit D (Table 5). 
Table (5): Relation between age, laboratory parameters and Lt Forearm $\mathbf{t}$ score in Cases

\begin{tabular}{|c|c|c|c|c|}
\hline $\begin{array}{c}\text { Lt Forearm t } \\
\text { score } \\
\text { Variables }\end{array}$ & $\begin{array}{c}\text { Normal } \\
(n=22)\end{array}$ & $\begin{array}{l}\text { Osteopenia } \\
\quad(n=17)\end{array}$ & $\begin{array}{c}\text { Osteoporosis } \\
\quad(n=11)\end{array}$ & $\begin{array}{c}P- \\
\text { value }\end{array}$ \\
\hline \multirow{2}{*}{$\begin{array}{l}\bullet \quad \text { Age } \\
\text { Mean } \pm \text { SD. }\end{array}$} & & & & \multirow{2}{*}{0.027} \\
\hline & $36.9 \pm 8.57$ & $28.9 \pm 10.02$ & $34.2 \pm 11.27$ & \\
\hline \multirow{2}{*}{$\begin{array}{l}\bullet \quad \text { PTH } \\
\text { Mean } \pm \text { SD. }\end{array}$} & & & & \multirow[t]{2}{*}{$<0.001$} \\
\hline & $99.4 \pm 57.55$ & $117.9 \pm 79.33$ & $296.5 \pm 107.34$ & \\
\hline \multirow{2}{*}{$\begin{array}{c}\text { S.Ca T } \\
\text { Mean } \pm \text { SD. }\end{array}$} & & & & \multirow{2}{*}{$<0.001$} \\
\hline & $8.9 \pm 0.65$ & $7.9 \pm 0.76$ & $7.9 \pm 0.54$ & \\
\hline \multirow{3}{*}{$\begin{array}{lr}\bullet & \text { S.Ca I } \\
\text { Mean } \pm \text { SD. } \\
\bullet \quad \text { Vit D } \\
\text { Mean } \pm \text { SD. }\end{array}$} & & & & \multirow{2}{*}{$<0.001$} \\
\hline & $1.7 \pm 0.80$ & $1.6 \pm 0.75$ & $0.9 \pm 0.09$ & \\
\hline & $16.1 \pm 7.68$ & $14.1 \pm 8.3$ & $5.9 \pm 3.25$ & $<0.001$ \\
\hline
\end{tabular}

Regarding to correlation between laboratory parameters and AP spine BMD in cases, there was negative correlation and significance between AP spine BMD in Cases with PTH while, positive correlation and significance between AP spine BMD in cases with s.Ca T\&I and Vit D (Table 6).

Table (6): Correlation between laboratory parameters and AP spine BMD in Cases

\begin{tabular}{|l|c|c|}
\hline Lab. Findings & r & P-value \\
\hline PTH & $\mathbf{- 0 . 4 4 8}$ & $\mathbf{0 . 0 0 1}$ \\
\hline SCa.T & $\mathbf{0 . 4 3 9}$ & $\mathbf{0 . 0 0 1}$ \\
\hline SCa.I & $\mathbf{0 . 3 0 7}$ & $\mathbf{0 . 0 2 9}$ \\
\hline Vit D & $\mathbf{0 . 4 2 5}$ & $\mathbf{0 . 0 0 2}$ \\
\hline
\end{tabular}

Regarding to correlation between laboratory parameters and Lt femur BMD in cases, there were negative correlation and significance between Lt femur BMD in cases with PTH while, positive correlation and significance between $\mathrm{Lt}$ femur BMD in cases with s.Ca T\&I and Vit D (Table 7).

Table (7): Correlation between laboratory parameters and Lt Femur BMD in Cases

\begin{tabular}{|l|c|c|}
\hline Lab. Findings & $\mathbf{r}_{\text {s }}$ & P-value \\
\hline PTH & $\mathbf{- 0 . 6 6 8}$ & $<0.001$ \\
\hline SCa.T & $\mathbf{0 . 5 0 7}$ & $<0.001$ \\
\hline SCa.I & $\mathbf{0 . 4 5 4}$ & $\mathbf{0 . 0 0 1}$ \\
\hline Vit D & $\mathbf{0 . 4 9 1}$ & $<\mathbf{0 . 0 0 1}$ \\
\hline
\end{tabular}

Regarding to correlation between laboratory parameters and $\mathrm{Lt}$ forearm BMD in Cases, there were negative correlation and significance between $\mathrm{Lt}$ forearm BMD in cases with $\mathrm{PTH}$, while positive correlation and significance between $\mathrm{Lt}$ forearm BMD in cases with S.Ca T\&I and Vit D (Table 8). 
Table (8): Correlation between laboratory parameters and Lt Forearm BMD in Cases

\begin{tabular}{|l|c|c|}
\hline Lab. Findings & $\mathbf{r}$ & P-value \\
\hline PTH & $\mathbf{- 0 . 6 0 0}$ & $<\mathbf{0 . 0 0 1}$ \\
\hline SCa.T & $\mathbf{0 . 4 4 1}$ & $\mathbf{0 . 0 0 1}$ \\
\hline SCa.I & $\mathbf{0 . 4 2 3}$ & $\mathbf{0 . 0 0 2}$ \\
\hline Vit D & 0.413 & 0.003 \\
\hline
\end{tabular}

Regarding to correlation between age, laboratory parameters and Vit D in Cases, there was negative correlation and significance between Vit D in Cases with
PTH While, positive correlation and significance between Vit D in cases with s.Ca T\&I and t score (AP spine, Lt femur, Lt forearm) (Table 9).

Table (9): Correlation between laboratory, bone parameters and Vit D in Cases

\begin{tabular}{|l|c|c|}
\hline Variables & $\mathbf{r}_{\mathrm{s}}$ & P-value \\
\hline Age & $\mathbf{- 0 . 1 8 7}$ & $\mathbf{0 . 1 8 9}$ \\
\hline PTH & $\mathbf{- 0 . 5 5 2}$ & $<\mathbf{0 . 0 0 1}$ \\
\hline SCa.T & $\mathbf{0 . 4 5 4}$ & $\mathbf{0 . 0 0 1}$ \\
\hline SCa.I & $\mathbf{0 . 3 6 6}$ & $\mathbf{0 . 0 0 8}$ \\
\hline AP spine t score & $\mathbf{0 . 4 6 5}$ & $\mathbf{0 . 0 0 1}$ \\
\hline Lt Femur t score & $\mathbf{0 . 4 9 6}$ & $<\mathbf{0 . 0 0 1}$ \\
\hline Lt Forearm t score & $\mathbf{0 . 5 6 1}$ & $<0.001$ \\
\hline
\end{tabular}

\section{DISCUSSION}

In our retrospective cohort study on fifty Egyptian patients diagnosed as secondary hyperparathyroidism with a mean age of $33.6 \pm 10.12$ years, mean PTH $148.1 \pm 109.65$ and mean vit D 13.2 \pm 8.14 . Another fifty age matched control group with a mean age of $39.7 \pm 7.45$ years, mean PTH $53.0 \pm 13.69$ and mean vit $\mathrm{D} 42.3 \pm 11.25$ were included in the study. The comparison between cases and controls regarding patients' characteristics revealed that the $\mathrm{Lt}$ forearm is the most affected site in case group with mean tscore $-1.2 \pm 1.57$, but the other bone parameters in both groups were normal. Thirty five patients were vit $\mathrm{D}$ deficient with mean $\mathrm{t}$-score of the $\mathrm{Lt}$ forearm $-1.6 \pm$ 1.48 (osteopenia), mean t-score of the AP spine $-1.1 \pm 1.40$ (osteopenia) and fifteen were vit $\mathrm{D}$ insufficient with normal t-score of all bone parameters in this group.

Normal AP spine t- score was in thirty patients, osteopenia in fifteen with mean values for serum $25(\mathrm{OH}) \mathrm{D}$ and PTH levels were $11.5 \pm 6.13 \mathrm{ng} / \mathrm{ml}$ and 145.8 $\pm 85.72 \mathrm{pg} / \mathrm{ml}$, respectively, and osteoporosis in five with mean values for serum 25(OH) D and PTH levels were 4.9 $\pm 2.76 \mathrm{ng} / \mathrm{ml}$ and $323.0 \pm 120.36 \mathrm{pg} / \mathrm{ml}$, respectively.

Normal Lt femur t- score in twenty eight patients, osteopenia in nineteen with mean values for serum $25(\mathrm{OH}) \mathrm{D}$ and PTH levels were $12.3 \pm 8.18 \mathrm{ng} / \mathrm{ml}$ and $190.0 \pm 126.19 \mathrm{pg} / \mathrm{ml}$, respectively, and osteoporosis in Three (3) with mean values for serum $25(\mathrm{OH}) \mathrm{D}$ and $\mathrm{PTH}$ 
levels were $5.8 \pm 3.32 \mathrm{ng} / \mathrm{ml}$ and $300.0 \pm 161.00 \mathrm{pg} / \mathrm{ml}$, respectively.

Normal Lt Forearm T- score in twenty two patients, osteopenia in seventeen with mean values for serum $25(\mathrm{OH}) \mathrm{D}$ and PTH levels were $14.1 \pm 8.37 \mathrm{ng} / \mathrm{ml}$ and $117.9 \pm 79.33 \mathrm{pg} / \mathrm{ml}$, respectively, and osteoporosis in eleven with mean values for serum 25(OH) D and PTH levels were $5.9 \pm 3.25 \mathrm{ng} / \mathrm{ml}$ and $296.5 \pm 107.34 \mathrm{pg} / \mathrm{ml}$, respectively.

Our study showed a statistically significant difference between cases and controls according to Age, PTH, Vit D, BMD and T score (AP spine, Lt Femur, Lt forearm). This result agreed with that of Mendes (2019) where age was positively correlated with BMD at the femur but not BMD at the lumbar spine. There were no significant differences between age groups in serum $25(\mathrm{OH}) \mathrm{D}$, plasma $\mathrm{PTH}$, and serum calcium. Kota (2013) at the hip; PTH levels and age were found to be significant predictors of BMD.at the lumbar spine; PTH levels and age were independently predictive of BMD.

Our study shows statistically significant difference between Vit D groups in Cases according to PTH. Negative correlation and significance between vit D in cases with PTH. This result agreed with that of Mendes (2019) who reported that $25(\mathrm{OH}) \quad \mathrm{D}$ concentrations being inversely correlated with PTH concentrations in healthy adult women. Additionally, $10.4 \%$ of participants had secondary hyperparathyroidism, with a higher prevalence amongst those with deficient and insufficient vitamin D status. $E l$ Badawy (2014) showed an inverse correlation between $25(\mathrm{OH}) \mathrm{D}$ and PTH.
Vučeljić et al., (2012) showed a very significant inverse correlation between $25(\mathrm{OH}) \mathrm{D}$ and PTH was established by BMD at lumbar spine. In patients with 25(OH) D insufficiencies, elevated PTH varied individually, but it was most often increased if $25(\mathrm{OH}) \mathrm{D}$ was equal or lower than $37.6 \mathrm{nmol} / \mathrm{L}$. Kota (2013) reported that a negative correlation between PTH and $25(\mathrm{OH}) \mathrm{D}$ at serum $25(\mathrm{OH}) \mathrm{D}$ concentrations $<30 \mathrm{ng} / \mathrm{ml}$.

Our study showed a statistically significant difference between Vit D groups in cases according to BMD \& $\mathrm{t}$ score (AP spine, Lt femur, Lt forearm). This result agreed with that of Mendes (2019) where no significant correlations between lumbar spine (L1-L4) and femur bone parameter measurements, determined by DXA, and $25(\mathrm{OH}) \mathrm{D}$ concentrations for women living in Brazil. Kota (2013) showed no statistically significant associations between serum $25(\mathrm{OH}) \mathrm{D}$ concentrations and BMD at the hip and lumbar spine. No direct relationship between serum $25(\mathrm{OH})$ D levels and BMD was observed. Vučeljić et al., (2012) showed very significant inverse correlations between $25(\mathrm{OH}) \mathrm{D}$ and PTH was established by BMD at lumbar spine. Alkhenizan (2017) reported that no significant correlation between spine or total femoral BMD and serum $25(\mathrm{OH}) \mathrm{D}$. No correlation has been found between vitamin $\mathrm{D}$ deficiency and reduced bone mineral density in any age group, in males or females.

Our study showed a statistically significant difference between AP spine $\mathrm{t}$ score in cases according to PTH, Vit D. Negative significant correlation between AP spines BMD in cases with PTH. 
While, positive correlation and significant between AP spine BMD in Cases with Vit D. Positive significant correlation between Vit D in cases with $t$ score (AP spine). This result agreed with that of Mendes (2019) where no significant correlations between lumbar spine (L1-L4) bone parameter measurements, determined by DXA, and 25(OH)D concentrations for women living in Brazil. Kota (2013) showed no statistically significant associations between serum 25(OH) D concentrations and BMD at lumbar spine. Alkhenizan (2017) reported that no significant correlation between spine BMD and serum 25(OH) D.

Our study showed a statistically significant difference between Lt femur $\mathrm{t}$ score in cases according to PTH. Negative significant correlation between Lt femur BMD in cases with PTH, while positive significant correlation between Lt femur BMD in cases with vit $\mathrm{D}$, and positive significant correlation between vit $\mathrm{D}$ in cases with $\mathrm{t}$ score (Lt femur). This result agreed with that of Mendes (2019) where no significant correlations between femur bone parameter measurements, determined by DXA, and 25(OH) D concentrations for women living in Brazil. Kota (2013) at the hip found that PTH levels were significant predictors of BMD. Di Monaco (2016) showed that PTH levels in the presence of severe vitamin D deficiency were significantly associated with femoral BMD in women. Amaozugan (2011) did not find any significant associations between PTH status and hip BMD.

Our study showed no statistically significant difference between Lt femur $\mathrm{t}$ score in cases according to Vit D. This result agreed with that of Alkhenizan (2017) who reported that no significant correlation between total femoral BMD and serum 25(OH) D. Kota (2013) showed no statistically significant associations between serum 25(OH) D concentrations and BMD at the hip. $D i$ Monaco (2016) showed the presence of secondary hyperparathyroidism which was significantly associated with a femoral neck t-score lower than -2.5.

Our study showed a statistically significant difference between Lt forearm $\mathrm{t}$ score in cases with PTH and Vit D. Negative significant correlation between $\mathrm{Lt}$ forearm BMD in cases with PTH, while positive significant correlation between $\mathrm{Lt}$ forearm BMD in cases with Vit $\mathrm{D}$, and positive significant correlation between Vit D in cases with $\mathrm{t}$ score ( $\mathrm{Lt}$ forearm).

Our study showed negative significant correlation between Vit D in cases with PTH, while positive significant correlation between Vit D in cases with s.Ca $\mathrm{T} \& \mathrm{I}$. This result agreed with that of El Badawy (2014) who showed an inverse correlation between 25(OH)D and PTH. Low calcium and ionized calcium are significantly correlated with vitamin D levels. LópezRamiro et al., (2016) showed an inverse association between serum 25OHD and PTH. Baroncini (2018) showed a negative correlation between PTH levels and 25(OH) D.

\section{CONCLUSION}

Positive significant correlation between Vit D with serum calcium (Total and Ionized), BMD and t score (AP spine, Lt femur, Lt forearm), negative significant correlation between BMD (AP spine, Lt femur, Lt forearm) with PTH, and 
negative significant correlation between vit D with PTH.

\section{REFERENCES}

1. Alkhenizan A., Mahmoud A., Hussain A., Gabr A. and Alsoghayer S. (2017): The Relationship between $25(\mathrm{OH})$ D Levels (Vitamin D) and Bone Mineral Density (BMD) in a Saudi Population in a Community-Based Setting. PLOS ONE 12(1): e0169122.

2. Amouzougan A, Chopin F, Laporte S, Vico $L$ and Thomas $T$ (2011): Functional hypoparathyroidism in postmenopausal women with fragility fracture. Joint Bone Spine, 79: 170-175.

3. Baroncini CV, Regalado TP, Borba VZC and Moreira CA (2018): Prevalence of hypovitaminosis D and secondary hyperparathyroidism in postmenopausal women. Rev Med (São Paulo), 97(4):378-84.

4. Charoenngam N, Rujirachun $P$ and Holick M.F (2019): Oral vitamin D3 supplementation increases serum fibroblast growth factor 23 concentration in vitamin Ddeficient patients: a systematic review and meta-analysis. Osteoporos Int., 10(4):30-35.

5. Di Monaco M., Castiglioni C. and Tappero R. (2016): Parathyroid hormone response to severe vitamin D deficiency is associated with femoral neck bone mineral density: an observational study of 405 women with hipfracture. Hormones, 15(4):527-533.

6. Ebeling PR., (2014): Vitamin D and bone health: epidemiologic studies. Bonekey Rep., 7(3):50-55.

7. El Badawy A., Aboserea M., El Seifi O., Mortada E. and Bakry H. (2014): Vitamin D, Parathormone and Associated Minerals among Students in Zagazig District, Sharkia Governorate, Egypt. Int J Vitam Nutr Res., 9(4):71-77.

8. Holick MF, Binkley NC, Bischoff-Ferrari HA, Gordon CM, Hanley DA and Heaney RP (2011): Evaluation, treatment and prevention of vitamin D deficiency: An Endocrine Society clinical practice guideline. J Clin Endocrinol Metab., 96:1911-30.

9. Kota S., Jammula S., Kota S., Meher L. and Modi K. (2013): Correlation of vitamin $\mathrm{D}$, bone mineral density and parathyroid hormone levels in adults with low bone density. Indian Journal of Orthopaedics., 47:402-7.

10. López-Ramiro E., Rubert M., Mahillo I. and de la Piedra C. (2016): Secondary hyperparathyroidism due to vitamin D deficiency. ORIGINALS, Rev Osteoporos Metab Miner., 8(2):55-60.

11. Mendes MM., Hart KH., Lanham-New SA. and Botelho PB. (2019): Association between 25-Hydroxyvitamin D, Parathyroid Hormone, Vitamin D and Calcium Intake, and Bone Density in Healthy Adult Women: A Cross-Sectional Analysis from the DSOLStudy. Nutrients, 11:1267-16.

12. Vučeljić M., Ilić-Stojanović O., Lazović M. and Grajić M. (2012): Vitamin D and parathyroid hormone in relation to bone mineral density in postmenopausal women. Vojnosanit Pregl., 69(3): 243-248. 
العلاقة بين مستوى فيتامين (د) وكثافة العظام عند المرضى المصريين المصابين بفرط

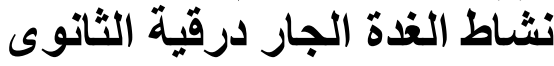

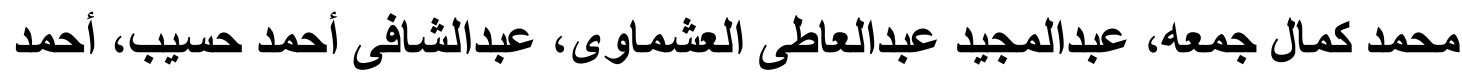

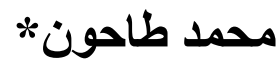

قسى الروماتيزم و التأهيل والباثولوجيا الاكلينيكيه٪، كلية الطب، جامعة الأزهر

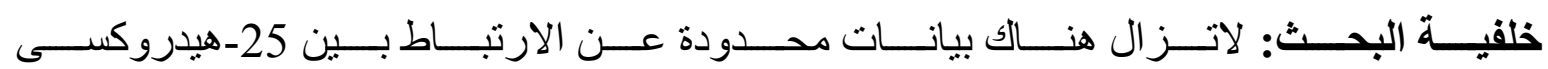
فيتامين د، وهرمون الغدة الجار درقية وكثافة العظام في مصر.

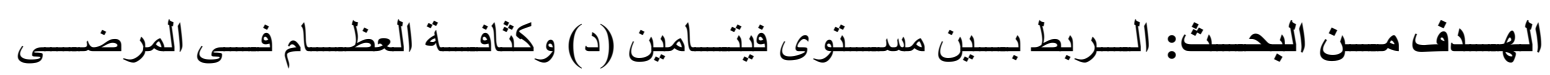
المصريين المصابين بفرط نشاط الغدة الجار درقية الثانوى.

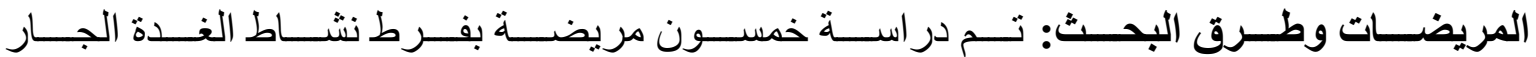

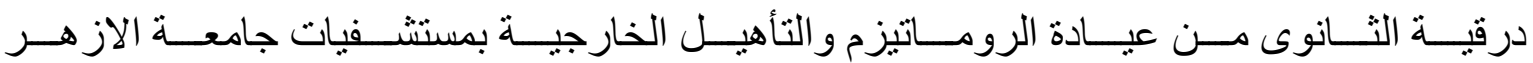

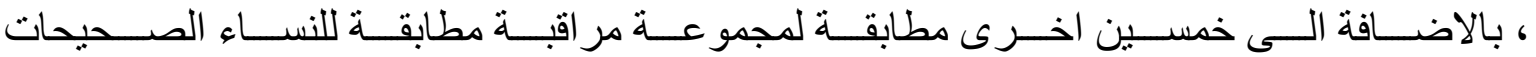

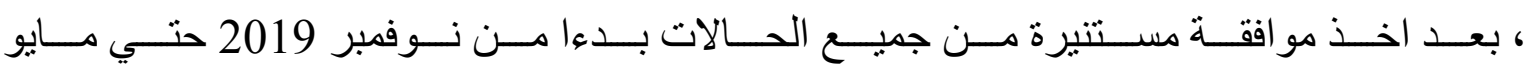

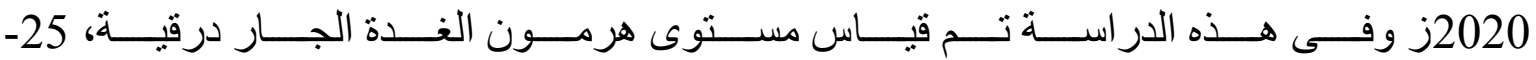

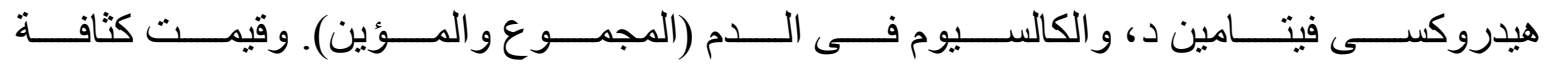

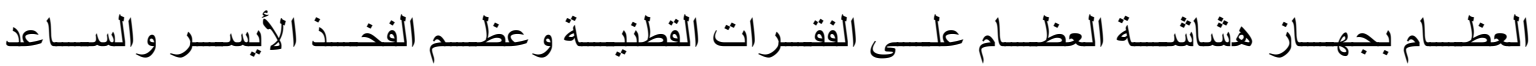

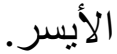

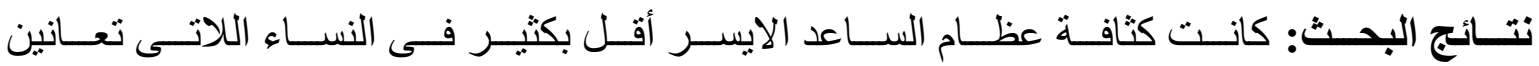

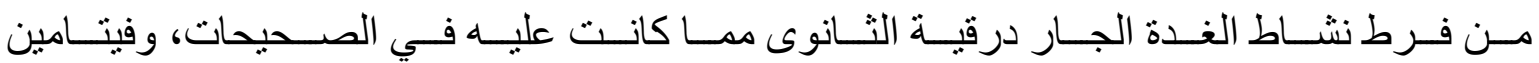
د كان ناقصا في 70 \% من المريضات.

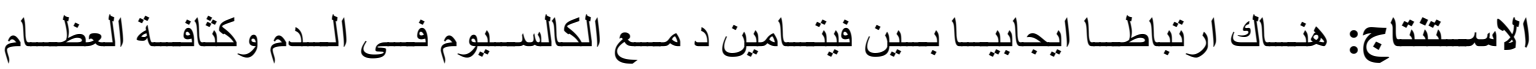

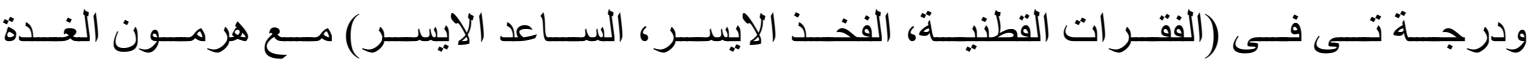
الجار درقية، وارتباط سلبى بين فيتامين د مع هرمون الغدة الجار درقية. 